\title{
Analysis on Background of Amending the Regulation on the Collective Management of Copyright in China
}

\author{
Qianxin Huang \\ Intellectual Property Research Institute of Xiamen University, Xiamen 361005, P. R. China \\ 1421115605@qq.com
}

\begin{abstract}
Collective management of copyright has already developed for more than 20 years in China. Regulation on the Collective Management of Copyright was issued and implemented in March 2005. However, the limitations of existing regulation became more pronounced as the emergence of new-media and the transformation of CMOs' functions. Accordingly, Regulation on Collective Management of Copyright needs to be amended and revised.
\end{abstract}

Keywords: Collective Management of Copyright; Collective Management Organizations; Copyright Law.

\section{Introduction}

According to theoretic definition the collective management is the exercise of copyright and related rights by organizations acting in the interest and on behalf of the owners of rights[1]. Nowadays, an author cannot negotiate every single radio or television station to get remuneration for the use of his works. Meanwhile, for example, it is not practical for a broadcasting organization to seek specific permission from every author for use of their copyrighted works. The impracticability of above activities, both for copyright owners and users, creates a need for copyright and related rights collective management organizations called "CMOs", which can balance the interests of copyright holders and users.

Historically, collective management of copyright was started in the $18^{\text {th }}$ century in Europe and already has more than 200 years of evolution and development. Early in its development, a collective management organization is generally formed by copyright holders to manage the rights in their copyright works[2]. These organizations ensure that creators receive payment for the use of their works[3]. In 1777, the famous French dramatist Beaumarchais established the first collective management of copyright organization in the world, called "Dramatist and Composer Association". Nowadays, collective management organizations, which are independent and private organization appointed by copyright owners, administer the licensing of rights, collection of royalties and enforcement of rights on copyright holder's behalf in name of organization. In practice, according to CMOs it is convenient for both the copyright holders, who cannot effectively exercise their right and the copyright works users, who cannot get license in effective way. Obviously, the collective management of copyright has contributed to the development of copyright or creative industries, which base on copyright materials. Therefore, with the development of copyright industries, the rules of collective management of copyright have been an important part of copyright law and a significant symbol of copyright protection level.

Across the globe, after hundreds of years of development and improvement, most developed countries have a complete and effective institution of collective management of copyright. However, in China the system of collective management of copyright is still in its infancy.

The collective management of copyright in China began in the 1990s. After The Copyright Law of People's Republic of China was issued in 1990, the National Copyright Administration approved to establish the first collective management of copyright organization - Music Copyright Society of China (called "MCSC") in 1992. Then in March 2005, Regulation on the Collective Management of Copyright was issued and implemented. Currently, China has already established five collective management of copyright organizations, which are all non-profit organizations. Meanwhile, these five collective management of copyright organizations were approved by National Copyright 
Administration of the People 's Republic of China (NCAC) and Ministry of Civil Affairs of the People 's Republic of China (MCA). Furthermore, each of them is the sole copyright collective management organization in particular copyright works fields, namely, Music Copyright Society of China("MCSC"), China Audio-Video Copyright Association("CAVCA"), China Written Works Copyright Society("CWWCS"), Images Copyright Society of China("ICSC") and China Film Copyright Association Collection ("CFCF-C").

By law, the main function of these collective management organizations is managing the right of performance, projection, broadcasting, dissemination through information network, reproduction, compilation, etc., and signing contract with copyright users, institute legal proceedings against the infringers, etc. Such activities of CMOs' is often referred to as Rights Management. And then the Management of Rights means that the aim of establishing these CMOs is to protect legal rights and interests of Copyright owners by means of regulating the use of Copyright works. Accordingly, the main work of these organizations is collecting copyright royalties from users and then distributing the royalties to their members, which called "Remuneration Distribution." At the same time, they have a responsibility to propagating the Copyright Law and promoting the copyright industry.

In a word, collective management of copyright has already developed more than 20 years in China. On one hand it exerts a great effect on protecting the rights of copyright owners and even facilitate the copyright industry. On the other hand, with the rapid development of disseminating technology, the copyright collective management organizations are facing a number of problems. Firstly, even in the 21 st Century, the sense for copyright protection in China is pending enhancement. Secondly, due to the short operating period the copyright collective management organizations lack experience and expertise in both rights management and remuneration distribution. Finally, the development of digital and information technology brings a great challenge of controlling the ways of using copyright works .Under these backgrounds, it is necessary to have further modification and improvement of Regulation on the Collective Management of Copyright 2005.

\section{The Background of Amending the Regulation}

Based on the analysis above, the following text elaborates the necessity and rationality of modification for Regulation on the Collective Management of Copyright 2005 in four perspectives.

From the perspective of technology innovation: Innovation in the field of social media brings great changes in creation, dissemination and usage mode of literary and artistic works, even create wide development space for the copyright industry. Obviously, these changes not only give authors many new capabilities, meanwhile enrich ways for users to acquire and use the copyright works. It means copyright holders can get royalties from many new ways. Under this situation, new social relationships which adjusted by legal have arisen. At the same time, many practical problems have been derived from the emergences of new social relationships, such as how the copyright owners to conclude licensing contract with users of copyright works effectively, how to protect users from violation of copyright laws, etc. Therefore, in order to resolve these problems, which caused by media technological development, the provisions of law need modification.

From the perspective of economic development: the copyright industry (known as "creative industry"), which based on copyright legal system, is becoming an important component of pillar industry in China. In reality, compare with traditional industries, the copyright or creative industry have advantage in terms of product structure and business model. For instance, it is known that in developed countries, such as Britain and the United States, the copyright industry has blossomed and facilitate economic growth significantly. Meanwhile, the contribution of the copyright-based industries to GDP and employment is growing sharply in recent years. These realities provide good references for China, which is in the period of economies transition. However, it should be realized that, the development of copyright industry is not only determined by objective situation, but also depends highly on well-established legal system. Consequently, the laws relating to copyright collective management need to reform. 
From the perspective of legal norms: China's first legislation on collective management of copyright called Regulation on the Collective Management of Copyright which was implemented officially on March 1st, 2005. It offered important institutional guarantees and legal base for the collective management of copyright in the following 10 years. Although these regulations have been revised in 2011, the shortcomings of them began to show up gradually under the influence of disseminating technology innovation, media reform and economic development. In some cases, the existing legal norms have a negative effect on the operational efficiency of copyright collective management organizations.

From the perspective of functional changes of collective management system: Theoretically, collective management system of copyright is to collect copyright royalties from users and to distribute copyright royalties to copyright owners. Accordingly, protecting lawful rights of copyright holders is the main function of this system. In that aspect, maximize benefits of copyright owners is the core foundation of the copyright collective management organizations. However, with the perfection of copyright collective management system in the world, the key of this system shifts from protecting individual copyright owner's interests to balance the interests between copyright owners and users, even safeguarding the public interests. This indicates that the copyright collective management system has to coordinate and balance the individual interests of copyright holders and the public interests. Under this background, the copyright collective management system is endowed with the mission or even duty of facilitating and promoting social culture development, which shall be reflected in legal norms.

\section{Conclusion}

Based on above analysis, it is clear that because of the emergence of new communication technologies, the social foundations of the copyright law and relevant regulations have been changed in China. And then the way of dissemination of literary and artistic works differs from those of past. These led to intensifying hysteresis of the Regulations on Collective Management of Copyright (2005) and made it fail to provide institutional guarantee and supports to new social issues in specific fields. It means that, in order to adapt to social development and promote the growth of copyright or creative industry, the legal norms relating to collective management of copyright system needs to adjust to the new status. Therefore, new social demands caused by technological reform are the direct reasons and main backgrounds of revision of the Regulations on Collective Management of Copyright. (2005) in China.

\section{References}

[1] http://www.wipo.int/copyright/en/management/ .[EB/OL].2016-4-25.

[2] http://www.ipos.gov.sg/AboutIP/TypesofIPWhatisIntellectualProperty/Whatiscopyright/copyrig htresources/CollectiveManagementOrganisations.aspx . [EB/OL].2016-4-26.

[3] http://www.wipo.int/publications/en/details.jsp?id=4039 .[EB/OL].2016-4-25.

[4] Regulations on Collective Administration of Copyright [J]. China Patents \& Trademarks, 2005.

[5] Karnell G, Lewinski S V, Schricker G. Collective administration of copyright and neighbouring rights [M]. Mohr Siebeck, M. Nijhoff, 2006.

[6] Vergara S, Santiago, Mello, et al. WIPO Panel 4. Collective Management of Copyright and Related Rights - Developing Countries and Regional Perspectives [J]. Vanderbilt University Law School, 2007.

[7] Left M S P. Access and Reward in the Information Society: Regulating the Collective Management of Copyright [J]. Social Science Electronic Publishing, 2007.

[8] Nérisson S. Has Collective Management of Copyright Run Its Course? Not so Fast [J]. IIC International Review of Intellectual Property and Competition Law, 2015, 46(5):505-507. 